\title{
Alogliptin benzoate for management of type 2 diabetes
}

\author{
This article was published in the following Dove Press journal: \\ Vascular Health and Risk Management \\ 10 April 2015 \\ Number of times this article has been viewed
}

\author{
Yoshifumi Saisho \\ Department of Internal Medicine, \\ Keio University School of Medicine, \\ Tokyo, Japan
}

\begin{abstract}
Dipeptidyl peptidase-4 (DPP-4) inhibitors, a new class of oral hypoglycemic agents, augment glucose-dependent insulin secretion and suppress glucagon levels through enhancement of the action of endogenous incretin by inhibiting DPP-4, an incretin-degrading enzyme. DPP-4 inhibitors are generally well tolerated because of their low risk of hypoglycemia and other adverse events. Moreover, with their potential to improve beta cell function, a core defect of type 2 diabetes, DPP-4 inhibitors are becoming a major component of treatment of type 2 diabetes. Alogliptin benzoate is a newly developed, highly selective DPP-4 inhibitor which has been approved in many countries throughout the world. Once-daily administration of alogliptin as either monotherapy or combination therapy with other oral antidiabetic drugs or insulin has a potent glucose-lowering effect which is similar to that of other DPP-4 inhibitors, with a low risk of hypoglycemia and weight gain. The cardiovascular safety of this drug has been confirmed in a recent randomized controlled trial. This review summarizes the efficacy and safety of alogliptin, and discusses the role of DPP-4 inhibitors in the treatment of type 2 diabetes.
\end{abstract}

Keywords: dipeptidyl peptidase- 4 inhibitor, type 2 diabetes, efficacy, safety, alogliptin

\section{Introduction}

Dipeptidyl peptidase-4 (DPP-4) inhibitors, a new class of oral hypoglycemic agents, augment glucose-dependent insulin secretion through enhancement of the action of endogenous incretin (ie, glucagon-like peptide-1 and glucose-dependent insulinotropic polypeptide) by inhibiting DPP-4, a degrading enzyme of incretin. DPP-4 inhibitors also suppress glucagon secretion via elevation of glucagon-like peptide-1. They are generally well tolerated because of their low risk of hypoglycemia and other adverse events. ${ }^{1}$

Alogliptin benzoate is a newly developed DPP-4 inhibitor developed by Takeda Inc (Osaka, Japan) that was approved for clinical use in the treatment of type 2 diabetes (T2DM) in Japan in April 2010 with the trade name Nesina ${ }^{\circledR}$. Alogliptin was also approved by the US Food and Drug Administration and the European Medicines Agency in January 2013 and September 2013, respectively (with the trade name Vipidia $^{\circledR}$ in Europe) and, as of September 2014, is available in 39 countries. In Japan, sitagliptin was the first approved DPP-4 inhibitor in December 2009, and first approved by the US Food and Drug Administration in 2006. Currently, seven DPP-4 inhibitors, ie, sitagliptin, vildagliptin, alogliptin, linagliptin, teneligliptin, anagliptin, and saxagliptin, have been approved in Japan.

Alogliptin was developed by structure-based design and proved to have high selectivity for DPP-4. ${ }^{2}$ The efficacy and safety of alogliptin has been confirmed to be similar 
to that of other DPP-4 inhibitors in recent clinical trials. ${ }^{3}$ This updated review of a previous publication ${ }^{4}$ focuses on the clinical efficacy and safety of alogliptin for the treatment of T2DM. The pharmacokinetics and pharmacodynamics of alogliptin have also been reviewed elsewhere. ., $^{5}$

\section{Methods}

This review is based upon a MEDLINE search and personal experience with alogliptin. A MEDLINE search (1966 to December 2014) for published clinical trials and pertinent review articles published in English was conducted with the keywords "alogliptin", "incretin", and "DPP-4 inhibitor". References of identified articles were searched for additional relevant sources. Relevant articles were also obtained from the author's personal list of references.

\section{Chemistry}

The chemical structure of alogliptin is shown in Figure 1. Alogliptin shows high selectivity for DPP-4 (>10,000-fold over other DPP isozymes such as DPP-2, DPP-8, and DPP-9., 2,7 High selectivity of alogliptin for DPP-4 has also been confirmed in a DPP-8/9-expressing cell model. ${ }^{8}$ A recent study using X-ray crystallography revealed that alogliptin interacts with the $\mathrm{S} 1$ and/or S2 subsites in addition to the S1 and S2 subsites of DPP-4, where vildagliptin interacts, suggesting that alogliptin offers more potent DPP-4 inhibition compared with vildagliptin. ${ }^{9}$

\section{Pharmacokinetics}

Alogliptin is rapidly absorbed after oral administration, with a median time taken to reach peak plasma concentration of 2 hours and a mean half-life of 12-21 hours across various doses (6.25-800 mg). Food does not affect the absorption of alogliptin. ${ }^{10-12}$



Figure I Chemical structure of alogliptin benzoate: 2-(\{6-[(3R)-3-aminopiperidin$\mid$ I-yl]-3-methyl-2,4-dioxo-3,4-dihydropyrimidin-I(2H)-yl\}methyl) benzonitrile monobenzoate.
To date, no drug interaction with alogliptin has been reported, although among the DPP-4 inhibitors, the level of saxagliptin may be affected by inhibitors or inducers of the cytochrome P450 3A4/5 isozyme (eg, ketoconazole, diltiazem, and rifampicin).

The pharmacokinetics of alogliptin have also been evaluated in subjects with renal and hepatic impairment. Following administration of a single $50 \mathrm{mg}$ dose of alogliptin, 1.7-fold, 2.1-fold, 3.2-fold, and 3.8-fold increases in alogliptin exposure in subjects with mild, moderate, severe renal insufficiency, and end-stage renal disease, respectively, were observed compared with levels in healthy volunteers. ${ }^{6,13}$ Thus, dose adjustment of alogliptin, as well as sitagliptin and saxagliptin, is recommended for patients with renal dysfunction (Table 1).

A single $25 \mathrm{mg}$ dose of alogliptin was administered to eight patients with moderate hepatic impairment based on the Child-Pugh Scale, and there was no significant increase in serum concentration of alogliptin when compared with that in healthy volunteers. Thus, dose adjustment of alogliptin is not needed in patients with hepatic impairment. ${ }^{6,13}$

\section{Pharmacodynamics}

Mean plasma DPP-4 inhibition after a single dose of alogliptin (25-800 $\mathrm{mg}$ ) ranged from $74 \%$ to $94 \%$ at 24 hours and $48 \%$ to $83 \%$ at 72 hours. After 14 days of dosing (25-400 mg/day), mean peak DPP-4 inhibition ranged from $94 \%$ to $99 \%$, with mean inhibition at 24 hours after dosing of $82 \%-97 \%$, supporting once-daily administration. ${ }^{10,11}$ A recent qualitative model of DPP-4 inhibition showed that with once-daily administration of alogliptin $25 \mathrm{mg}$, the usual recommended dosage of alogliptin, the percentage of time when DPP-4 inhibition was $>80 \%$ was $88 \%$, the percentage of DPP-4 inhibition at trough was $80 \%$, and the percentage of weighted average DPP-4 inhibition over 24 hours was $88 \%$, which is comparable with the results with once-daily administration of sitagliptin $100 \mathrm{mg}$. ${ }^{14}$

Table I Dosage modification of alogliptin for patients with renal impairment in Japan

Mild ( $\mathrm{CCr} \geq 50 \mathrm{~mL} / \mathrm{min})$ : no dosage adjustment required

(25 mg once daily)

Moderate ( $\mathrm{CCr} \geq 30$ to $<50 \mathrm{~mL} / \mathrm{min}$ ): decrease dose to $12.5 \mathrm{mg}$

once daily

Severe (CCr $<30 \mathrm{~mL} / \mathrm{min})$ : decrease dose to $6.25 \mathrm{mg}$ once daily*

Note: *Can be administered without regard to timing of hemodialysis. Abbreviation: $\mathrm{CCr}$, creatinine clearance. 


\section{Clinical efficacy \\ Glucose-lowering effect}

The glucose-lowering effect of alogliptin has been evaluated in double-blind, placebo-controlled Phase II and III trials and also in recent Phase IV trials. The results of major clinical trials assessing the clinical efficacy of alogliptin compared with placebo or active comparators are summarized in Table 2.

\section{Monotherapy}

To evaluate the efficacy of alogliptin as monotherapy, 329 drug-naïve patients with poorly controlled T2DM (mean $\mathrm{HbA}_{1 \mathrm{c}} 7.9 \%$ ) were randomized to once-daily treatment with alogliptin $12.5 \mathrm{mg}$, alogliptin $25 \mathrm{mg}$, or placebo for 26 weeks. ${ }^{15}$ At week 26 , the reduction in $\mathrm{HbA}_{1 \mathrm{c}}$ from baseline was $-0.56 \%$ and $-0.59 \%$ in the alogliptin $12.5 \mathrm{mg}$ and $25 \mathrm{mg}$ groups, respectively, compared with $0.02 \%$ in the placebo group $(P<0.001)$. Another dose-ranging study examined the efficacy of alogliptin $(6.25-50 \mathrm{mg})$ in 480 drug-naïve Japanese patients with T2DM. ${ }^{16} \mathrm{HbA}_{1 \mathrm{c}}$ at week 12 was dosedependently reduced by alogliptin, and the reduction in $\mathrm{HbA}_{1 \mathrm{c}}$ from baseline was $-0.68 \%$ and $-0.77 \%$ in the alogliptin 12.5 $\mathrm{mg}$ and $25 \mathrm{mg}$ groups, respectively, compared with $0.05 \%$ in the placebo group $(P<0.0001)$.

\section{Combination with other antidiabetic medications \\ Sulfonylureas}

The efficacy of alogliptin in combination with sulfonylureas has also been evaluated. ${ }^{17}$ In one study, 500 patients with T2DM inadequately controlled by sulfonylurea monotherapy (mean $\mathrm{HbA}_{1 \mathrm{c}}$ 8.1\%) were randomized to treatment with glyburide plus alogliptin $12.5 \mathrm{mg}$ or $25 \mathrm{mg}$ or placebo for 26 weeks. At week 26, the reduction in $\mathrm{HbA}_{1 \mathrm{c}}$ was $-0.38 \%$ and $-0.52 \%$ with alogliptin $12.5 \mathrm{mg}$ and $25 \mathrm{mg}$, respectively, compared with $0.01 \%$ for placebo $(P<0.001)$. In another study, 312 Japanese patients with T2DM inadequately controlled by sulfonylurea monotherapy (mean $\mathrm{HbA}_{1 \mathrm{c}} 8.5 \%$ ) were randomized to alogliptin $12.5 \mathrm{mg}$ or $25 \mathrm{mg}$ or placebo in addition to glimepiride $1-4 \mathrm{mg}$ for 12 weeks. ${ }^{18} \mathrm{The} \mathrm{HbA}_{1 \mathrm{c}}$ reduction at week 12 was $-0.59 \%$ and $-0.65 \%$ with alogliptin $12.5 \mathrm{mg}$ and $25 \mathrm{mg}$, respectively, compared with $0.35 \%$ for placebo $(P<0.0001)$.

\section{Metformin}

The efficacy of alogliptin in combination with metformin was evaluated in a study that included 527 patients with T2DM inadequately controlled on metformin monotherapy (mean $\mathrm{HbA}_{1 \mathrm{c}} 8 \%$ ). ${ }^{19}$ The patients were randomized to add-on treatment with alogliptin $12.5 \mathrm{mg}$ or $25 \mathrm{mg}$ or placebo for 26 weeks. At week 26, the reduction in $\mathrm{HbA}_{1 \mathrm{c}}$ with either dose of alogliptin was $-0.6 \%$ ( $P<0.001$ versus placebo). In another Japanese study, a total of 288 patients with T2DM inadequately controlled with metformin 500 or $750 \mathrm{mg}$ /day (mean $\mathrm{HbA}_{1 \mathrm{c}} 8.0 \%$ ) were randomized to receive alogliptin $12.5 \mathrm{mg}$ or $25 \mathrm{mg}$ or placebo in addition to metformin for 12 weeks. ${ }^{20}$ At week 12, the reduction in $\mathrm{HbA}_{1 \mathrm{c}}$ was $-0.55 \%$ and $-0.64 \%$ with alogliptin $12.5 \mathrm{mg}$ and $25 \mathrm{mg}$, respectively, compared with $0.22 \%$ for placebo $(P<0.0001)$.

Two more studies have been published recently. One trial was designed to evaluate the efficacy of initial therapy with alogliptin plus metformin. ${ }^{21} \mathrm{~A}$ total of 784 drug-naïve patients (mean $\mathrm{HbA}_{1 \mathrm{c}} 8.45 \%$ ) were randomized to receive placebo, alogliptin $12.5 \mathrm{mg}$ twice daily or $25 \mathrm{mg}$ once daily, metformin $500 \mathrm{mg}$ or $1,000 \mathrm{mg}$ twice daily, or a combination of alogliptin $12.5 \mathrm{mg}$ plus metformin $500 \mathrm{mg}$ or $1,000 \mathrm{mg}$ twice daily. The reduction in $\mathrm{HbA}_{1 \mathrm{c}}$ at week 26 was $-1.22 \%$ and $-1.55 \%$ with the combination of alogliptin $12.5 \mathrm{mg}$ plus metformin $500 \mathrm{mg}$ or $1,000 \mathrm{mg}$ twice daily, respectively, compared with $-0.52 \%$ and $-1.11 \%$ with alogliptin $25 \mathrm{mg}$ once daily and metformin $1,000 \mathrm{mg}$ twice daily, respectively $(P<0.001)$. The number of patients who achieved $\mathrm{HbA}_{1 \mathrm{c}}<7 \%$ was greater for combination therapy compared with monotherapy $(47.1 \%-59.5 \%$ versus $20.2 \%-34.3 \%)$. The second study was designed to compare the long-term efficacy and safety of alogliptin plus metformin with that of glipizide plus metformin..$^{22} \mathrm{~A}$ total of 2,639 patients with a mean age 55.4 years, a mean duration of diabetes of 5.5 years, and a mean $\mathrm{HbA}_{1 \mathrm{c}}$ of $7.6 \%$ were randomized to receive alogliptin $12.5 \mathrm{mg}$ or $25 \mathrm{mg}$ once daily or glipizide $5-20 \mathrm{mg}$ once daily in addition to metformin for 104 weeks. The $\mathrm{HbA}_{1 \mathrm{c}}$ reduction at week 104 was significantly greater with alogliptin $25 \mathrm{mg}$ than with glipizide $(-0.72 \%$ versus $-0.59 \%, P=0.010)$, with less hypoglycemia (1.4\% versus $23.2 \%)$ and weight gain $(-0.89$ versus $0.95 \mathrm{~kg}, P<0.001)$.

\section{Thiazolidinediones}

The efficacy of alogliptin in combination with a thiazolidinedione (TZD) was also evaluated. A total of 493 patients with T2DM inadequately controlled on a TZD (mean $\mathrm{HbA}_{1 \mathrm{c}}$ $8.0 \%$ ) were randomized to treatment with pioglitazone plus alogliptin $12.5 \mathrm{mg}$, alogliptin $25 \mathrm{mg}$, or placebo for 26 weeks. ${ }^{23}$ At week 26, the reduction in $\mathrm{HbA}_{1 \mathrm{c}}$ was $-0.66 \%$ with alogliptin $12.5 \mathrm{mg}$ and $-0.80 \%$ with alogliptin $25 \mathrm{mg}$, compared with $-0.19 \%$ for placebo $(P<0.001)$. In another Japanese study, ${ }^{24} 339$ patients with T2DM inadequately controlled on pioglitazone (mean $\mathrm{HbA}_{1 \mathrm{c}} 7.9 \%$ ) were randomized 


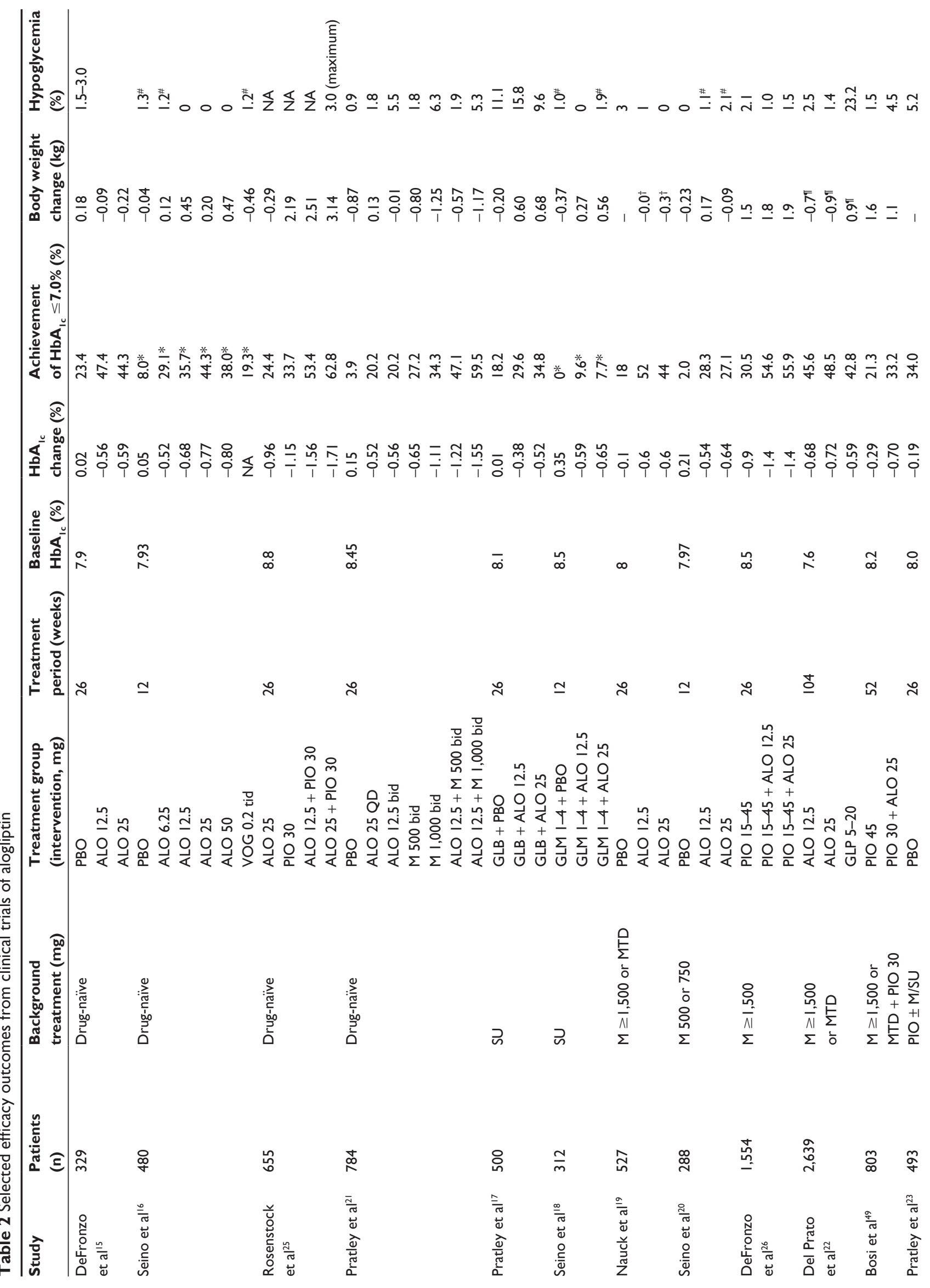




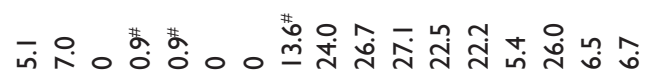

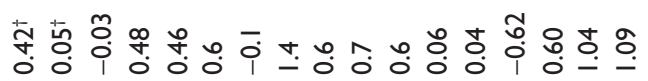

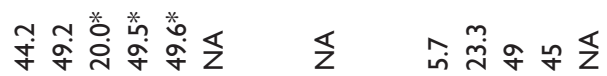

웅 웅 형



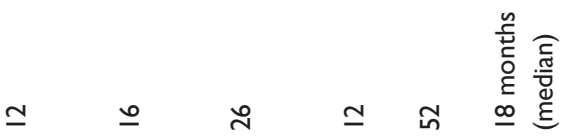

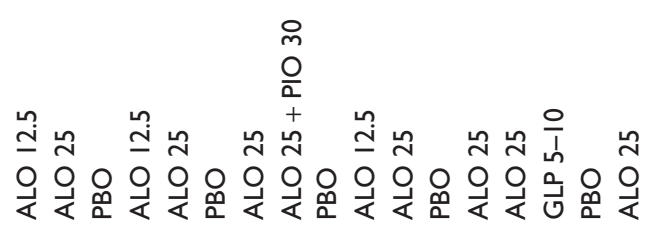

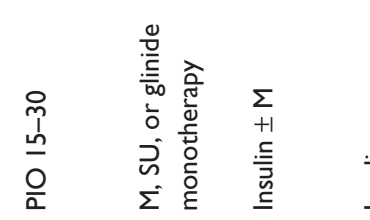

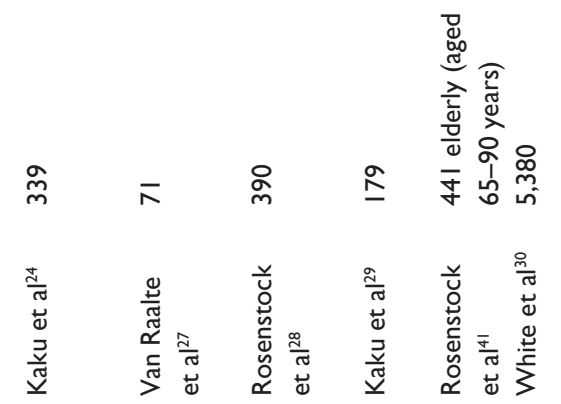

to add-on treatment with alogliptin $12.5 \mathrm{mg}$, alogliptin 25 $\mathrm{mg}$, or placebo for 12 weeks. At week 12, the reduction in $\mathrm{HbA}_{1 \mathrm{c}}$ was $-0.91 \%$ with alogliptin $12.5 \mathrm{mg}$ and $-0.97 \%$ with alogliptin $25 \mathrm{mg}$ compared with $-0.19 \%$ for placebo $(P<0.001)$.

Initial combination therapy of alogliptin and pioglitazone in drug-naïve patients with T2DM was also evaluated. A total of 655 drug-naïve patients with inadequately controlled diabetes (mean $\mathrm{HbA}_{1 \mathrm{c}}$ 8.8\%) were randomized into four treatment arms: alogliptin $25 \mathrm{mg}$ monotherapy, pioglitazone $30 \mathrm{mg}$ monotherapy, or alogliptin $12.5 \mathrm{mg}$ or $25 \mathrm{mg}$ plus pioglitazone $30 \mathrm{mg}$ combination therapy for 26 weeks. ${ }^{25} \mathrm{At}$ week 26 , combination therapy with alogliptin $25 \mathrm{mg}$ plus pioglitazone $30 \mathrm{mg}$ resulted in a greater reduction of $\mathrm{HbA}_{1 \mathrm{c}}$ $(-1.7 \%)$ versus alogliptin $25 \mathrm{mg}$ monotherapy $(-1.0 \%)$ or pioglitazone $30 \mathrm{mg}$ monotherapy $(-1.2 \% ; P<0.001)$.

Combination therapy with alogliptin and pioglitazone in addition to metformin monotherapy was evaluated in another study. ${ }^{26} \mathrm{~A}$ total of 1,554 patients with T2DM inadequately controlled on metformin monotherapy (mean $\mathrm{HbA}_{1 \mathrm{c}}$ $8.5 \%$ ) were randomized to add-on treatment with alogliptin $(12.5 \mathrm{mg}$ or $25 \mathrm{mg}$ ) alone or combined with pioglitazone (15, 30 , or $45 \mathrm{mg}$ ) for 26 weeks. At week 26, the reduction in $\mathrm{HbA}_{1 \mathrm{c}}$ was $-0.9 \%$ in the pioglitazone alone group and $-1.4 \%$ in the alogliptin $12.5 \mathrm{mg}$ and alogliptin $25 \mathrm{mg}$ plus pioglitazone groups $(P<0.001)$.

The efficacy of a combination of alogliptin and pioglitazone was also evaluated in another study. ${ }^{27}$ Seventy-one patients with well-controlled T2DM (mean $\mathrm{HbA}_{1 \mathrm{c}} 6.7 \%$ ) treated with metformin, sulfonylurea, or glinide monotherapy were randomized to receive alogliptin $25 \mathrm{mg}$ plus pioglitazone $30 \mathrm{mg}$, alogliptin $25 \mathrm{mg}$ monotherapy, or placebo for 16 weeks. The reduction in $\mathrm{HbA}_{1 \mathrm{c}}$ at week 16 was $-0.9 \%,-0.4 \%$, and $0.4 \%$, respectively ( $P<0.001$ versus placebo).

Insulin

The efficacy of alogliptin when added to insulin therapy in patients with T2DM was assessed in two trials. In one study, 390 patients with T2DM inadequately controlled with insulin alone or combined with metformin (mean $\mathrm{HbA}_{1 \mathrm{c}} 9.3 \%$ ) were randomized to receive add-on therapy with alogliptin $12.5 \mathrm{mg}$, alogliptin $25 \mathrm{mg}$, or placebo for 26 weeks. ${ }^{28}$ At week 26, the reduction in $\mathrm{HbA}_{1 \mathrm{c}}$ was $-0.63 \%$ with alogliptin $12.5 \mathrm{mg}$ and $-0.71 \%$ with alogliptin $25 \mathrm{mg}$, compared with $-0.13 \%$ for placebo $(P<0.001)$. In another Japanese study, 179 patients with T2DM inadequately controlled with insulin monotherapy were randomized to receive alogliptin $25 \mathrm{mg}$ or placebo in addition to insulin 
therapy for 12 weeks. ${ }^{29}$ The $\mathrm{HbA}_{1 \mathrm{c}}$ reduction at week 12 was $-0.96 \%$ for alogliptin compared with $-0.29 \%$ for placebo $(P<0.0001)$. The proportion of patients who achieved $\mathrm{HbA}_{1 \mathrm{c}}$ $<7 \%$ was greater with alogliptin than with placebo $(23.3 \%$ versus $5.7 \%$ ).

Lastly, the large-scale, randomized, controlled EXAMINE (Examination of Cardiovascular Outcomes with Alogliptin versus Standard of Care) study was conducted to assess the cardiovascular safety of alogliptin. ${ }^{30}$ In this study, treatment with alogliptin on top of other antidiabetic medications showed a significant reduction in $\mathrm{HbA}_{1 \mathrm{c}}(-0.36 \%, P<0.001)$ compared with placebo during a median follow-up of 18 months.

Recently, Berhan et al conducted a meta-analysis of ten randomized controlled trials to assess the efficacy of alogliptin in T2DM. ${ }^{3}$ The pooled standardized mean difference for the reduction in $\mathrm{HbA}_{1 \mathrm{c}}$ in patients treated with alogliptin $12.5 \mathrm{mg}$ was $-0.81 \%$ (95\% confidence interval $[\mathrm{CI}]-1.11,-0.51)$ and that in patients treated with alogliptin $25 \mathrm{mg}$ was $-0.98 \%(95 \% \mathrm{CI}-1.30,-0.66)$. The standardized mean difference of the reduction in fasting plasma glucose in patients treated with alogliptin $25 \mathrm{mg}$ was $-0.51 \mathrm{mmol} / \mathrm{L}$ (95\% CI -0.68, -0.34).

Although there has been no head-to-head trial comparing the efficacy of alogliptin with that of other DPP-4 inhibitors, the improvement of $\mathrm{HbA}_{1 \mathrm{c}}$ seen with alogliptin seems to be in the same range as that seen with other DPP-4 inhibitors, ${ }^{31,32}$ with the exception of vildagliptin $50 \mathrm{mg}$ twice daily, which was reported to have a small advantage in glucose-lowering effect compared with other DPP-4 inhibitors. ${ }^{33-35}$

\section{Predictors of $\mathrm{HbA}_{\mathrm{Ic}}$ reduction by DPP-4 inhibitors}

Recent meta-analyses of randomized controlled trials have shown that the efficacy of DPP-4 inhibitors is mainly related to baseline $\mathrm{HbA}_{1 \mathrm{c}}$ level, as is seen with other antidiabetic medications. ${ }^{36,37}$ Esposito et al examined the clinical characteristics that predict the $\mathrm{HbA}_{1 \mathrm{c}}$ response to DPP-4 inhibitors in their meta-regression analysis of 78 randomized controlled trials with 20,053 patients, and found a greater absolute reduction of baseline $\mathrm{HbA}_{1 \mathrm{c}}$ in patients with higher baseline $\mathrm{HbA}_{1 \mathrm{c}}$ and lower fasting glucose levels. ${ }^{37}$

Recent meta-analyses have also suggested the efficacy of incretin therapy differs between ethnic groups. It has been shown that the efficacy of $\mathrm{HbA}_{1 \mathrm{c}}$ reduction by DPP-4 inhibitors or glucagon-like peptide-1 receptor agonists is greater in Asian populations than in non-Asian populations, ${ }^{38,39}$ suggesting that lower body mass index is associated with a better $\mathrm{HbA}_{1 \mathrm{c}}$ response to incretin therapy.

The long-term glycemic durability of DPP-4 inhibitors in patients with T2DM has also been reported. A meta-analysis of 12 trials with 14,829 patients showed that the effect of DPP-4 inhibitors on $\mathrm{HbA}_{1 \mathrm{c}}$ declined significantly by $\sim 0.2 \%$ during the second year of treatment, ${ }^{40}$ while a greater $\mathrm{HbA}_{1 \mathrm{c}}$ reduction at 2 years was reported for alogliptin compared with glipizide in the above-mentioned trial. ${ }^{22}$

\section{Efficacy in the elderly}

The efficacy of alogliptin in the elderly was evaluated in a randomized, double-blind, active-controlled study. ${ }^{41}$ In this study, 441 elderly type 2 diabetic patients of mean age 70 (range 65-90) years and with mild hyperglycemia on diet/ exercise therapy alone or combined with oral antidiabetic monotherapy (mean $\mathrm{HbA}_{1 \mathrm{c}} 7.5 \%$ ) were randomized to alogliptin $25 \mathrm{mg}$ or glipizide 5-10 mg for 52 weeks. The reduction in $\mathrm{HbA}_{1 \mathrm{c}}$ at the end of study was $-0.42 \%$ with alogliptin and $-0.33 \%$ with glipizide, demonstrating no inferiority of alogliptin to glipizide. A post hoc analysis using this cohort showed that the proportion of patients achieving $\mathrm{HbA}_{1 \mathrm{c}} \leq 7.0 \%$ without hypoglycemia or weight gain was significantly higher with alogliptin than with glipizide $(24 \%$ versus $13 \%, P<0.03) .{ }^{42}$ It has also been shown that patients with baseline $\mathrm{HbA}_{1 \mathrm{c}}<8.0 \%$ receiving alogliptin are also more likely to achieve $\mathrm{HbA}_{1 \mathrm{c}} \leq 7.0 \%$ without hypoglycemia or weight gain than those receiving glipizide (29\% versus $13 \%, P<0.03){ }^{42}$

A pooled analysis of Phase II and III studies to assess the efficacy of alogliptin in elderly patients with T2DM has also been reported. ${ }^{43}$ Analysis of six randomized controlled trials of alogliptin showed a similar improvement in $\mathrm{HbA}_{1 \mathrm{c}}$ in elderly patients (mean age 70 years) compared with younger patients (mean age 52 years).

\section{Efficacy in hemodialysis patients}

Since alogliptin is excreted by the kidney, the dose of alogliptin should be reduced in patients with moderate to severe renal impairment, as shown in Table 1. In a single-arm study, treatment with alogliptin $6.25 \mathrm{mg}$ reduced $\mathrm{HbA}_{1 \mathrm{c}}$ and glycated albumin levels from $7.1 \% \pm 0.2 \%$ to $5.8 \% \pm 1.6 \%$ and from $22.5 \% \pm 0.7 \%$ to $19.6 \% \pm 0.6 \%$, respectively, after 24 months in 16 hemodialysis patients with T2DM. ${ }^{44}$

\section{Effect on beta cell function}

Alogliptin has been shown to improve beta cell function and increase beta cell mass in rodents. ${ }^{45-48}$ In humans, it 
was reported that there was no or only modest improvement of beta cell function assessed by proinsulin to insulin ratio or homeostasis model assessment (HOMA)- $\beta$ by alogliptin monotherapy or combination therapy with metformin or a sulfonylurea. ${ }^{15,17,19}$ On the other hand, significant improvement of beta cell function was reported when patients were treated with alogliptin combined with pioglitazone. ${ }^{24,26,49}$ It has been reported that treatment with a combination of alogliptin $25 \mathrm{mg}$ and pioglitazone $30 \mathrm{mg}$ for 16 weeks significantly improved beta cell glucose sensitivity and fasting secretory tone compared with placebo, while alogliptin $25 \mathrm{mg}$ monotherapy did not change beta cell function parameters. ${ }^{27}$ A recent study has shown that treatment with alogliptin improved the function and proliferation of adult human beta cells engrafted in diabetic immunodeficient mice; ${ }^{50}$ however, the effect of DPP-4 inhibitors on beta cell mass in humans remains unclear. ${ }^{51}$

\section{Effect on lipids}

Eliasson et al reported a change in postprandial lipids during treatment with alogliptin. ${ }^{52}$ Seventy-one patients with inadequately controlled T2DM were randomized to treatment with alogliptin $25 \mathrm{mg}$, alogliptin $25 \mathrm{mg}$ plus pioglitazone $30 \mathrm{mg}$, or placebo for 16 weeks. At 16 weeks, a significant reduction in postprandial triacylglycerol and triacylglycerol-rich lipoproteins was observed with alogliptin monotherapy and alogliptin plus pioglitazone combination therapy compared with placebo. A meta-analysis of 17 studies $^{53}$ also showed a significant reduction in total cholesterol $(-0.18 \mathrm{mmol} / \mathrm{L}$ $[-7 \mathrm{mg} / \mathrm{dL}])$ and triacylglycerol $(-0.15 \mathrm{mmol} / \mathrm{L}[-13 \mathrm{mg} /$ dL]) on treatment with a DPP-4 inhibitor, although the reduction was small. A separate analysis of the effect of individual DPP-4 inhibitors showed a significant reduction in total cholesterol with alogliptin and vildagliptin, but not with sitagliptin. ${ }^{53}$ However, in the EXAMINE study, no significant difference in lipoprotein levels was found between the alogliptin and placebo groups. ${ }^{30}$

\section{Effect on atherosclerosis and cardiovascular events}

In animal studies, it was reported that alogliptin suppressed the progression of atherosclerosis in diabetic mice through downregulation of proinflammatory cytokines. ${ }^{54,55}$ It was also reported that alogliptin reduced the volume of the infarct lesion and neurological deficit after the induction of temporary focal ischemia in nondiabetic male $\mathrm{C} 57 \mathrm{BL} / 6 \mathrm{~J}$ mice, ${ }^{56}$ suggesting that the neuroprotective effect of alogliptin is independent of its glucose-lowering effect.
The effect of DPP-4 inhibitors on atherosclerosis in humans is unclear. In a preliminary study of ten healthy volunteers, treatment with alogliptin $25 \mathrm{mg}$ for 1 week significantly suppressed the postprandial elevation in serum triacylglycerol and improved postprandial endothelial dysfunction, as assessed by brachial artery flow-mediated dilation. $^{57}$

\section{Effect on kidney function}

Although a protective effect of DPP-4 inhibitors against renal injury has been reported in rodent studies, ${ }^{58-61}$ the presence of such an effect remains to be established in humans. It has been reported that switching from sitagliptin to alogliptin, combined with an angiotensin II type 1 receptor blocker, resulted in a significant reduction in the urinary albumin to creatinine ratio in 12 patients with T2DM and albuminuria. ${ }^{62}$ This improvement in albuminuria was accompanied by an elevated plasma level of stromal cell-derived factor-1 alpha and a decrease in urinary 8-hydroxy-2'-deoxyguanosine, an oxidative stress marker, suggesting that alogliptin ameliorated albuminuria by reducing oxidative stress. Sakata et al reported that treatment with alogliptin for 12 weeks significantly reduced the urinary albumin to creatinine ratio, as well as $\mathrm{HbA}_{1 \mathrm{c}}$ and the circulating soluble form of the receptor for advanced glycation end products, in 61 patients with T2DM. ${ }^{63}$

In the EXAMINE trial, no difference in change in estimated glomerular filtration rate was reported between alogliptin and placebo. ${ }^{30}$ On the other hand, fewer patients showed worsened urinary albumin to creatinine ratio with saxagliptin versus placebo in the SAVOR (Saxagliptin Assessment of Vascular Outcomes Recorded in Patients with Diabetes Mellitus)-TIMI (Thrombolysis in Myocardial Infarction) 53 trial, ${ }^{64}$ although it remains unclear whether this effect of a DPP-4 inhibitor is independent of its glucose-lowering effect.

The effect of DPP-4 inhibitors on other types of microangiopathy such as retinopathy and neuropathy in humans remains largely unknown. ${ }^{65}$

\section{Safety}

In general, the incidence of adverse events with DPP-4 inhibitors is reported to be low, and these agents are well tolerated.

\section{Hypoglycemia}

The risk of hypoglycemia is low on treatment with alogliptin. The incidence of hypoglycemia with alogliptin was reported to be as low as that with placebo or metformin monotherapy 
and lower than that with sulfonylureas. ${ }^{15,17,19,41}$ Adding alogliptin to insulin therapy resulted in improvement of $\mathrm{HbA}_{1 \mathrm{c}}$, without increasing hypoglycemia compared with insulin therapy alone. ${ }^{28,29}$ However, use of a DPP-4 inhibitor as combination therapy with a sulfonylurea can increase the risk of hypoglycemia. ${ }^{1}$ Therefore, caution is needed when a DPP-4 inhibitor is added to a sulfonylurea, especially in patients at risk of hypoglycemia, such as the elderly, patients with renal impairment, patients treated with a high dose of sulfonylureas, and patients with autonomic neuropathy.

\section{Effect on body weight}

The effect of DPP-4 inhibitors on body weight is generally reported to be neutral. ${ }^{1}$ Treatment with alogliptin has shown less weight gain compared with sulfonylureas. ${ }^{22,41}$ It was reported that alogliptin neither prevented nor exacerbated weight gain when it was combined with pioglitazone. ${ }^{23-26,49}$

\section{Cardiovascular safety}

Recently, regulatory agencies have created cardiovascular safety guidelines for the development of therapies for diabetes. A pooled analysis of alogliptin trials including 4,168 patients showed no sign of increased cardiovascular risk with alogliptin in patients with T2DM (hazard ratio, $0.635,95 \%$ CI 0.0-1.41). ${ }^{66}$

The results of the EXAMINE study assessing the longterm cardiovascular safety of alogliptin were published in September $2013 .{ }^{30}$ In this study, 5,380 patients with T2DM and recent acute coronary syndrome were randomized to receive alogliptin or placebo in addition to existing antihyperglycemic therapy. During a median follow-up period of 1.8 years, the rate of major adverse cardiovascular events, a composite of death from cardiovascular causes, nonfatal myocardial infarction, and nonfatal stroke, was not increased with alogliptin compared with placebo (11.3\% versus $11.8 \%$, hazard ratio 0.96 ; upper boundary of one-sided repeated CI, 1.16; $P<0.001$ for noninferiority).

Another cardiovascular outcome trial of a DPP-4 inhibitor was published at the same time. The SAVOR-TIMI 53 trial $^{64}$ was designed to evaluate the safety and efficacy of saxagliptin with respect to cardiovascular outcomes in patients with T2DM and at risk of a cardiovascular event. A total of 16,492 patients were randomized to receive saxagliptin or placebo and followed for a median of 2.1 years. There was no significant difference in incidence of a primary endpoint event, a composite of cardiovascular death, myocardial infarction, and ischemic stroke, between the groups (hazard ratio $1.00,95 \%$ CI $0.89-1.12 ; P=0.99$ for superiority; $P<0.001$ for noninferiority).
The results of these two randomized controlled trials confirmed the cardiovascular safety of DPP-4 inhibitors. However, in the SAVOR-TIMI 53 trial, more patients in the saxagliptin group than in the placebo group were hospitalized for heart failure (3.5\% versus $2.8 \%$; hazard ratio 1.27 , 95\% CI 1.07-1.51, $P=0.007) .{ }^{64}$ Meta-analyses of trials using different DPP-4 inhibitors including alogliptin also suggested an increased risk of heart failure with DPP-4 inhibitor treatment, ${ }^{67,68}$ although in the EXAMINE study the incidence of heart failure was not significantly increased in the alogliptin group (hazard ratio $1.19,95 \%$ CI $0.89-1.58, P=0.24$ ). ${ }^{30}$ Further investigation is needed to clarify whether DPP-4 inhibitors are associated with a risk of heart failure.

\section{Other adverse events}

Angioedema has been reported as an adverse event of DPP-4 inhibitors, especially when combined with an angiotensinconverting enzyme inhibitor. ${ }^{69}$ We have had a patient who developed facial angioedema after the introduction of vildagliptin, which improved after switching from vildagliptin to alogliptin. ${ }^{70}$ The incidence of angioedema due to DPP-4 inhibitors is generally low, and no difference in its incidence was reported between the alogliptin and placebo groups in the EXAMINE trial. ${ }^{30}$

To date, no meta-analyses of clinical trials or large-scale, randomized controlled trials of DPP-4 inhibitors suggest any increase in specific adverse events, such as nasopharyngitis, upper respiratory tract infection, skin reaction, hepatotoxicity, or pancreatitis, with the exception of heart failure as described above. ${ }^{1,30,64,71,72}$ Concern has been raised regarding the risk of pancreatitis or pancreatic cancer associated with incretin therapy; ${ }^{73,74}$ however, no increase in the incidence of acute pancreatitis has been reported in patients treated with incretin therapy in recent health insurance claims database and case-control studies, ${ }^{75,76}$ or in randomized controlled trials. ${ }^{30,64}$ Although case reports of liver injury in patients treated with alogliptin have raised the question of possible hepatotoxicity with this agent, no evidence of liver injury was reported in the EXAMINE trial. ${ }^{30,77}$ Completion of pooled analysis of ongoing long-term, large-scale clinical trials is needed to determine the longer-term safety profile, such as the incidence of cancer (Table 3).

Table 3 Issues concerning dipeptidyl peptidase-4 inhibitors in need of further clarification

- Hepatotoxicity

- Heart failure

- Pancreatitis

- Pancreatic cancer 


\section{Role of DPP-4 inhibitors in treatment of T2DM}

It is now well appreciated that not only type 1 diabetes but also T2DM is characterized by a deficit of beta cells. ${ }^{78-81}$ Beta cell dysfunction is a strong predictor of future development of T2DM, ${ }^{82-87}$ suggesting that beta cell dysfunction is a core pathogenetic feature of the disease. Further, beta cell function in patients with T2DM progressively declines with duration of disease and is negatively associated with glycemic control. ${ }^{88-92}$ Thus, preservation or recovery of beta cell function is an important treatment strategy in T2DM. ${ }^{93}$

Despite recent advances in the treatment of T2DM, several issues remain to be resolved (Table 4), all of which are related to nonphysiological, inappropriate insulin supplementation by treatment, such as with sulfonylureas or insulin. In contrast, DPP-4 inhibitors have benefits with respect to all these issues (Table 4). Further, DPP-4 inhibitors improve the dynamics of glucagon, ${ }^{94,95}$ whereas raised plasma glucagon levels and a paradoxical increase in postprandial glucagon are another major defect in diabetes. ${ }^{96}$ Therefore, one of the most important characteristics of DPP-4 inhibitors is recovery of endogenous insulin (and glucagon) secretion in a more physiological fashion compared with previous antidiabetic medications.

A proposed concept with regard to a treatment strategy for T2DM in relation to beta cell function is shown in Figure 2. T2DM is a progressive disease, and usually medication needs to be uptitrated with time. ${ }^{97}$ Currently, the most effective strategy to preserve or restore beta cell function is to reduce the beta cell workload. ${ }^{98}$ Since metformin reduces the insulin demand and beta cell workload by lowering hepatic glucose production, use of metformin in addition to lifestyle modification should be considered at as early a stage of diabetes as possible, unless contraindicated. In addition to the glucose-lowering efficacy of metformin, the less weight gain

Table 4 Remaining issues in the treatment of type 2 diabetes and potential of DPP-4 inhibitors

\begin{tabular}{|c|c|}
\hline Remaining issues & $\begin{array}{l}\text { Potential of DPP-4 } \\
\text { inhibitors }\end{array}$ \\
\hline Hypoglycemia & Low risk of hypoglycemia \\
\hline Weight gain & Neutral effect on body weight \\
\hline Postprandial hyperglycemia & Reduce glycemic variability \\
\hline $\begin{array}{l}\text { Concern about increased risk of } \\
\text { malignancy and/or atherosclerosis due } \\
\text { to systemic (peripheral) hyperinsulinemia } \\
\text { (especially with insulin therapy) }\end{array}$ & $\begin{array}{l}\text { Restore endogenous } \\
\text { insulin secretion in a more } \\
\text { physiological manner }\end{array}$ \\
\hline Progressive decline in beta cell function & Improve beta cell function \\
\hline
\end{tabular}

Abbreviation: DPP-4, dipeptidyl peptidase-4.

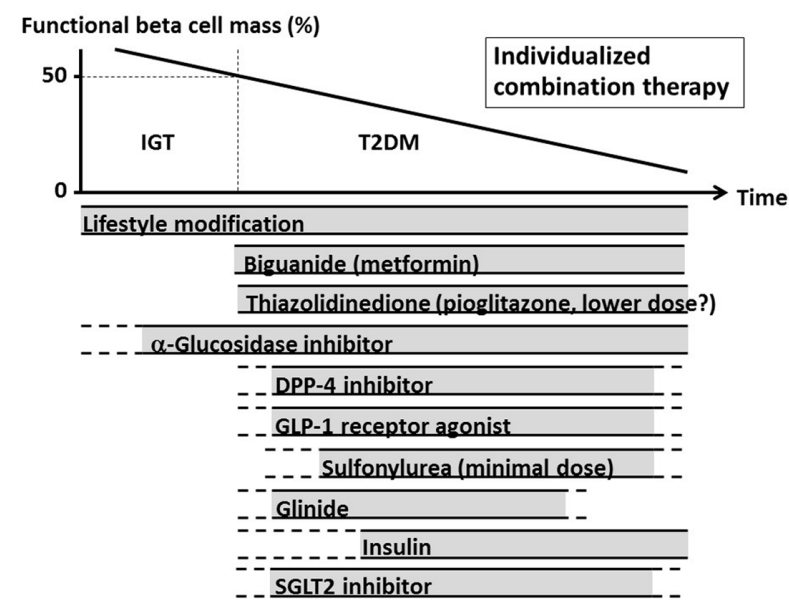

Figure 2 Proposed concept of treatment strategy for T2DM in relation to beta cell function.

Notes: T2DM is a progressive disease, and usually medication needs to be uptitrated with time. Currently, the most effective way to preserve or restore beta cell function is to reduce beta cell workload. Since metformin reduces insulin demand and beta cell workload through lowering hepatic glucose production, the use of metformin in addition to lifestyle modification should be considered at as early a stage of diabetes as possible, unless contraindicated. In Japan, alpha-glucosidase inhibitors are approved for clinical use in patients with impaired glucose tolerance and metabolic syndrome, in addition to T2DM. Since DPP-4 inhibitors are expected to improve beta cell function in addition to their glucose-lowering effect, the use of DPP-4 inhibitors can also be considered for a broad range of disease stages. In contrast, the use of insulin secretagogues, sulfonylureas, may not be considered as initial therapy but rather for use at a lower dose to support the insulinotropic effect of incretin therapy. Since to date no drug can cure diabetes, combination therapy should be considered in most cases. Triple combination therapy with metformin, pioglitazone, and alogliptin has been shown to be effective in reducing $\mathrm{HbA}_{\mathrm{Ic}}$ and improving beta cell function. Medications not approved in Japan are not included in the figure. Copyright (C) 2015. The Author. Reproduced from Saisho Y. Beta cell dysfunction: its critical role in prevention and management of type 2 diabetes. World J Diabetes. 2015;6(I):109-124. ${ }^{93}$

Abbreviations: IGT,impaired glucose tolerance;T2DM, type 2 diabetes;DPP-4, dipeptidyl peptidase-4; GLP-I, glucagon-like peptide-I;SGLT2, sodium-glucose cotransporter 2.

or modest weight loss, low risk of hypoglycemia, and low cost of this drug support metformin as a first-line treatment for T2DM, as recommended in most guidelines. ${ }^{99-101}$ Other non-insulin secretagogues, such as TZDs, alpha-glucosidase inhibitors, and sodium-glucose cotransporter 2 inhibitors should also be considered as treatment options to reduce beta cell workload, in addition to their clinical utility, ie, low risk of hypoglycemia.

On the other hand, although DPP-4 inhibitors are "insulin secretagogues", they are expected to improve beta cell function in addition to having a glucose-lowering effect and other advantages, as described in Table 4. Therefore, use of DPP-4 inhibitors can be considered for a broad range of disease stages. Combination therapy with metformin and a DPP-4 inhibitor is expected to have high glucose-lowering efficacy, a low risk of hypoglycemia, less weight gain or modest weight loss, and a low risk of adverse events, except for the gastrointestinal side effects of metformin, as described in a meta-analysis. ${ }^{102}$ 





The glucose-lowering effect of TZDs has been shown to have greater durability compared with that of sulfonylureas or even metformin. ${ }^{103}$ Thus, combination therapy with a DPP-4 inhibitor and a TZD is also expected to have a glucose-lowering effect with high efficacy and durability and a low risk of hypoglycemia, and to effectively improve beta cell function. ${ }^{27}$ However, since TZDs are associated with weight gain, weight reduction should not be expected. In addition, a risk of bladder cancer and bone fractures are a concern with TZDs, although a recent large cohort study showed no increased risk of bladder cancer in patients treated with pioglitazone. ${ }^{104}$ Thus, it might be advisable to use TZDs such as pioglitazone at a lower dosage to reduce the risk of adverse effects.

Fixed-dose combination tablets of alogliptin and metformin $\left(\right.$ Kazano $\left.^{\circledR}\right)$ or pioglitazone $\left(\right.$ Liovel $^{\circledR}$ or Oseni ${ }^{\circledR}$ ) are now available in many countries. It has been reported that use of fixed-dose combination tablets improves patient adherence to treatment and treatment satisfaction, ${ }^{105,106}$ possibly resulting in improved glycemic control. Thus, fixed-dose combinations containing alogliptin will be an important option for the treatment of T2DM. A combination of a DPP-4 inhibitor and another non-insulin secretagogue such as an alpha-glucosidase inhibitor or sodium-glucose cotransporter 2 inhibitor has also been shown to be effective for improving $\mathrm{HbA}_{1 \mathrm{c}}$ and glycemic variability, ${ }^{107,108}$ with a low risk of hypoglycemia and weight neutrality or modest weight loss, although gastrointestinal disturbance with alpha-glucosidase inhibitors often limits their use. The long-term efficacy and safety of the combination of a DPP-4 inhibitor and a sodium-glucose cotransporter 2 inhibitor remains to be established.

In contrast, sulfonylureas (insulin secretagogues) may not be considered as initial therapy, but rather for use at a lower dose to support the insulinotropic effect of incretin therapy, because of their risk of hypoglycemia and weight gain. Glinides, short-acting insulin secretagogues, correct postprandial hyperglycemia. Although the glucose-lowering effect of glinides is modest, the risk of hypoglycemia with glinides is lower than that with sulfonylureas. Therefore, combined use of a DPP-4 inhibitor and a glinide may be useful to manage postprandial hyperglycemia while minimizing the risk of hypoglycemia and weight gain.

Insulin shows the greatest efficacy in reducing $\mathrm{HbA}_{1 \mathrm{c}}$, and has been shown to improve beta cell function. ${ }^{109,110}$ Thus, combination of a DPP-4 inhibitor and insulin should be considered for patients with various stages of T2DM, although the risk of hypoglycemia, weight gain, and fear or unwillingness to carry out injections may limit this combination. The efficacy of combination of a DPP-4 inhibitor and a glucagon-like peptide-1 agonist remains to be determined.

Since there is no drug to date that can cure diabetes, combination therapy should be considered in most cases. To date, on top of metformin, each combination of antidiabetic medication has its advantages and disadvantages (Table 5). The results of the ACCORD (Action to Control Cardiovascular Risk in Diabetes) study have warned us not to simply intensify medical treatment to reduce $\mathrm{HbA}_{1 \mathrm{c}}$ to near-normal levels. ${ }^{111}$ Hospital admission rates for hypoglycemia now exceed those for hyperglycemia among older adults. ${ }^{112}$ The burden of medical treatment may rather result in reducing the patient's quality-adjusted life years. ${ }^{113}$ Therefore, each combined drug should be selected for each individual patient with consideration of the patient's preference. ${ }^{99,114}$ Although studies suggest that initial combination therapy reduces $\mathrm{HbA}_{1 \mathrm{c}}$ more effectively than monotherapy in the short term, ${ }^{21,25}$ the longer-term efficacy remains unknown.

It has been reported that the glucose-lowering effect of DPP-4 inhibitors is more potent in Asians than in Caucasians. ${ }^{38}$ Moreover, recent studies suggest that there is a difference in the pathophysiological features of T2DM according to ethnicity. ${ }^{115-117}$ Thus, the above-mentioned treatment strategy may not be applicable to other ethnicities or countries, and may need to be modified in each situation.

\section{Conclusion}

Alogliptin, a highly selective DPP-4 inhibitor, has a glucoselowering effect, the degree of which is similar to that of other DPP-4 inhibitors, with a low risk of hypoglycemia and weight gain. The safety of alogliptin, including cardiovascular adverse events, has been confirmed in a large-scale trial. Having a low risk of hypoglycemia, weight neutrality, and the potential to improve beta cell function, DPP-4 inhibitors are expected to become an important component of the treatment of T2DM. In Japan, currently more than half of patients with T2DM are treated with DPP-4 inhibitors. The cost-effectiveness of DPP-4 inhibitors needs to be assessed in future trials.

\section{Acknowledgment}

The author is grateful to Dr Wendy Gray for editing the manuscript.

\section{Disclosure}

The author reports no conflicts of interest in this work. 


\section{References}

1. Karagiannis T, Paschos P, Paletas K, Matthews DR, Tsapas A. Dipeptidyl peptidase-4 inhibitors for treatment of type 2 diabetes mellitus in the clinical setting: systematic review and meta-analysis. $B M J$. 2012;344:e1369.

2. Feng J, Zhang Z, Wallace MB, et al. Discovery of alogliptin: a potent, selective, bioavailable, and efficacious inhibitor of dipeptidyl peptidase IV. J Med Chem. 2007;50(10):2297-2300.

3. Berhan A, Berhan Y. Efficacy of alogliptin in type 2 diabetes treatment: a meta-analysis of randomized double-blind controlled studies. BMC Endocr Disord. 2013;13(1):9.

4. Saisho Y. Alogliptin for the treatment of type 2 diabetes. J Symptoms Signs. 2014;3(1):26-34.

5. Rendell M, Drincic A, Andukuri R. Alogliptin benzoate for the treatment of type 2 diabetes. Expert Opin Pharmacother. 2012;13(4):553-563.

6. White JR. Alogliptin for the treatment of type 2 diabetes. Drugs Today (Barc). 2011;47(2):99-107.

7. Lee B, Shi L, Kassel DB, Asakawa T, Takeuchi K, Christopher RJ. Pharmacokinetic, pharmacodynamic, and efficacy profiles of alogliptin, a novel inhibitor of dipeptidyl peptidase-4, in rats, dogs, and monkeys. Eur J Pharmacol. 2008;589(1-3):306-314.

8. Huan Y, Jiang Q, Liu J-L, Shen Z-F. Establishment of a dipeptidyl peptidases (DPP) 8/9 expressing cell model for evaluating the selectivity of DPP4 inhibitors. J Pharmacol Toxicol Methods. 2015;71:8-12.

9. Nabeno M, Akahoshi F, Kishida H, et al. A comparative study of the binding modes of recently launched dipeptidyl peptidase IV inhibitors in the active site. Biochem Biophys Res Commun. 2013;434(2): 191-196.

10. Christopher R, Covington P, Davenport M, et al. Pharmacokinetics, pharmacodynamics, and tolerability of single increasing doses of the dipeptidyl peptidase- 4 inhibitor alogliptin in healthy male subjects. Clin Ther. 2008;30(3):513-527.

11. Covington P, Christopher R, Davenport M, et al. Pharmacokinetic, pharmacodynamic, and tolerability profiles of the dipeptidyl peptidase-4 inhibitor alogliptin: a randomized, double-blind, placebo-controlled, multiple-dose study in adult patients with type 2 diabetes. Clin Ther. 2008;30(3):499-512.

12. Karim A, Covington P, Christopher R, et al. Pharmacokinetics of alogliptin when administered with food, metformin, or cimetidine: a two-phase, crossover study in healthy subjects. Int J Clin Pharmacol Ther. 2010;48(1):46-58.

13. Baetta R, Corsini A. Pharmacology of dipeptidyl peptidase-4 inhibitors: similarities and differences. Drugs. 2011;71(11):1441-1467.

14. Gibbs JP, Fredrickson J, Barbee T, et al. Quantitative model of the relationship between dipeptidyl peptidase-4 (DPP-4) inhibition and response: meta-analysis of alogliptin, saxagliptin, sitagliptin, and vildagliptin efficacy results. J Clin Pharmacol. 2012;52(10): 1494-1505.

15. DeFronzo RA, Fleck PR, Wilson CA, Mekki Q. Efficacy and safety of the dipeptidyl peptidase-4 inhibitor alogliptin in patients with type 2 diabetes and inadequate glycemic control: a randomized, double-blind, placebo-controlled study. Diabetes Care. 2008;31(12): 2315-2317.

16. Seino Y, Fujita T, Hiroi S, Hirayama M, Kaku K. Efficacy and safety of alogliptin in Japanese patients with type 2 diabetes mellitus: a randomized, double-blind, dose-ranging comparison with placebo, followed by a long-term extension study. Curr Med Res Opin. 2011;27(9): 1781-1792.

17. Pratley RE, Kipnes MS, Fleck PR, Wilson C, Mekki Q. Efficacy and safety of the dipeptidyl peptidase-4 inhibitor alogliptin in patients with type 2 diabetes inadequately controlled by glyburide monotherapy. Diabetes Obes Metab. 2009;11(2):167-176.

18. Seino Y, Hiroi S, Hirayama M, Kaku K. Efficacy and safety of alogliptin added to sulfonylurea in Japanese patients with type 2 diabetes: a randomized, double-blind, placebo-controlled trial with an open-label, long-term extension study. J Diabetes Invest. 2012;3(6): $517-525$.
19. Nauck MA, Ellis GC, Fleck PR, Wilson CA, Mekki Q. Efficacy and safety of adding the dipeptidyl peptidase- 4 inhibitor alogliptin to metformin therapy in patients with type 2 diabetes inadequately controlled with metformin monotherapy: a multicentre, randomised, double-blind, placebo-controlled study. Int J Clin Pract. 2009;63(1): $46-55$.

20. Seino Y, Miyata Y, Hiroi S, Hirayama M, Kaku K. Efficacy and safety of alogliptin added to metformin in Japanese patients with type 2 diabetes: a randomized, double-blind, placebo-controlled trial with an openlabel, long-term extension study. Diabetes Obes Metab. 2012;14(10): 927-936.

21. Pratley RE, Fleck P, Wilson C. Efficacy and safety of initial combination therapy with alogliptin plus metformin versus either as monotherapy in drug-naïve patients with type 2 diabetes: a randomized, double-blind, 6-month study. Diabetes Obes Metab. 2014;16(7):613-621.

22. Del Prato S, Camisasca R, Wilson C, Fleck P. Durability of the efficacy and safety of alogliptin compared with glipizide in type 2 diabetes mellitus: a 2-year study. Diabetes Obes Metab. 2014;16(12): 1239-1246.

23. Pratley RE, Reusch JE, Fleck PR, Wilson CA, Mekki Q. Efficacy and safety of the dipeptidyl peptidase-4 inhibitor alogliptin added to pioglitazone in patients with type 2 diabetes: a randomized, double-blind, placebo-controlled study. Curr Med Res Opin. 2009;25(10):2361-2371.

24. Kaku K, Itayasu T, Hiroi S, Hirayama M, Seino Y. Efficacy and safety of alogliptin added to pioglitazone in Japanese patients with type 2 diabetes: a randomized, double-blind, placebo-controlled trial with an open-label long-term extension study. Diabetes Obes Metab. 2011; 13(11):1028-1035.

25. Rosenstock J, Inzucchi SE, Seufert J, Fleck PR, Wilson CA, Mekki Q. Initial combination therapy with alogliptin and pioglitazone in drugnaive patients with type 2 diabetes. Diabetes Care. 2010;33(11): 2406-2408.

26. DeFronzo RA, Burant CF, Fleck P, Wilson C, Mekki Q, Pratley RE. Efficacy and tolerability of the DPP-4 inhibitor alogliptin combined with pioglitazone, in metformin-treated patients with type 2 diabetes. J Clin Endocrinol Metab. 2012;97(5):1615-1622.

27. Van Raalte DH, van Genugten RE, Eliasson B, et al. The effect of alogliptin and pioglitazone combination therapy on various aspects of $\beta$-cell function in patients with recent-onset type 2 diabetes. Eur $J$ Endocrinol. 2014;170(4):565-574.

28. Rosenstock J, Rendell MS, Gross JL, Fleck PR, Wilson CA, Mekki Q. Alogliptin added to insulin therapy in patients with type 2 diabetes reduces $\mathrm{HbA}(1 \mathrm{C})$ without causing weight gain or increased hypoglycaemia. Diabetes Obes Metab. 2009;11(12):1145-1152.

29. Kaku K, Mori M, Kanoo T, Katou M, Seino Y. Efficacy and safety of alogliptin added to insulin in Japanese patients with type 2 diabetes: a randomized, double-blind, 12-week, placebo-controlled trial followed by an open-label, long-term extension phase. Expert Opin Pharmacother. 2014;15(15):2121-2130.

30. White WB, Cannon CP, Heller SR, et al. Alogliptin after acute coronary syndrome in patients with type 2 diabetes. $N$ Engl J Med. 2013;369(14): 1327-1335.

31. Aroda VR, Henry RR, Han J, et al. Efficacy of GLP-1 receptor agonists and DPP-4 inhibitors: meta-analysis and systematic review. Clin Ther. 2012;34(6):1247-1258. e1222.

32. Craddy P, Palin H-J, Johnson KI. Comparative effectiveness of ddipeptidylpeptidase-4 iinhibitors in type 2 diabetes: a systematic review and mixed treatment comparison. Diabetes Ther. 2014;5(1):1-41.

33. Marfella R, Barbieri M, Grella R, Rizzo MR, Nicoletti GF, Paolisso G. Effects of vildagliptin twice daily vs. sitagliptin once daily on 24-hour acute glucose fluctuations. J Diabetes Complications. 2010; 24(2):79-83.

34. Signorovitch JE, Wu EQ, Swallow E, Kantor E, Fan L, Gruenberger JB. Comparative efficacy of vildagliptin and sitagliptin in Japanese patients with type 2 diabetes mellitus: a matching-adjusted indirect comparison of randomized trials. Clin Drug Invest. 2011;31(9):665-674. 
35. Sakamoto M, Nishimura R, Irako T, Tsujino D, Ando K, Utsunomiya K. Comparison of vildagliptin twice daily vs sitagliptin once daily using continuous glucose monitoring (CGM): crossover pilot study (J-VICTORIA study). Cardiovasc Diabetol. 2012;11:92.

36. DeFronzo RA, Stonehouse AH, Han J, Wintle ME. Relationship of baseline HbA1c and efficacy of current glucose-lowering therapies: a meta-analysis of randomized clinical trials. Diabet Med. 2010;27(3): 309-317.

37. Esposito K, Chiodini P, Capuano A, Maiorino M, Bellastella G, Giugliano D. Baseline glycemic parameters predict the hemoglobin A1c response to DPP-4 inhibitors. Endocrine. 2014;46(1):43-51.

38. Kim YG, Hahn S, Oh TJ, Kwak SH, Park KS, Cho YM. Differences in the glucose-lowering efficacy of dipeptidyl peptidase-4 inhibitors between Asians and non-Asians: a systematic review and meta-analysis Diabetologia. 2013;56(4):696-708.

39. Kim YG, Hahn S, Oh TJ, Park KS, Cho YM. Differences in the HbA1clowering efficacy of glucagon-like peptide-1 analogues between Asians and non-Asians: a systematic review and meta-analysis. Diabetes Obes Metab. 2014;16(10):900-909.

40. Esposito K, Chiodini P, Maiorino MI, Bellastella G, Capuano A, Giugliano D. Glycaemic durability with dipeptidyl peptidase-4 inhibitors in type 2 diabetes: a systematic review and meta-analysis of longterm randomised controlled trials. BMJ Open. 2014;4(6):e005442.

41. Rosenstock J, Wilson C, Fleck P. Alogliptin versus glipizide monotherapy in elderly type 2 diabetes mellitus patients with mild hyperglycaemia: a prospective, double-blind, randomized, 1-year study. Diabetes Obes Metab. 2013;15(10):906-914.

42. Bron M, Wilson C, Fleck P. A post hoc analysis of HbA1c, hypoglycemia, and weight change outcomes with alogliptin vs glipizide in older patients with type 2 diabetes. Diabetes Ther. 2014;5:521-534.

43. Pratley RE, McCall T, Fleck PR, Wilson CA, Mekki Q. Alogliptin use in elderly people: a pooled analysis from phase 2 and 3 studies. $J \mathrm{Am}$ Geriatr Soc. 2009;57(11):2011-2019.

44. Nakamura Y, Inagaki M, Shimizu T, et al. Long-term effects of alogliptin benzoate in hemodialysis patients with diabetes: a 2-year study. Nephron Clin Pract. 2013;123(1-2):46-51.

45. Moritoh Y, Takeuchi K, Asakawa T, Kataoka O, Odaka H. Chronic administration of alogliptin, a novel, potent, and highly selective dipeptidyl peptidase-4 inhibitor, improves glycemic control and beta-cell function in obese diabetic ob/ob mice. Eur J Pharmacol. 2008;588(2-3):325-332.

46. Kawashima S, Matsuoka TA, Kaneto H, et al. Effect of alogliptin, pioglitazone and glargine on pancreatic beta-cells in diabetic $\mathrm{db} / \mathrm{db}$ mice. Biochem Biophys Res Commun. 2011;404(1):534-540.

47. Zhang X, Wang Z, Huang Y, Wang J. Effects of chronic administration of alogliptin on the development of diabetes and beta-cell function in high fat diet/streptozotocin diabetic mice. Diabetes Obes Metab. 2011; 13(4):337-347.

48. Yin H, Park SY, Wang XJ, et al. Enhancing pancreatic beta-cell regeneration in vivo with pioglitazone and alogliptin. PLoS One. 2013;8(6) e65777.

49. Bosi E, Ellis GC, Wilson CA, Fleck PR. Alogliptin as a third oral antidiabetic drug in patients with type 2 diabetes and inadequate glycaemic control on metformin and pioglitazone: a 52-week, randomized, doubleblind, active-controlled, parallel-group study. Diabetes Obes Metab. 2011;13(12):1088-1096.

50. Jurczyk A, Diiorio P, Brostowin D, et al. Improved function and proliferation of adult human beta cells engrafted in diabetic immunodeficient NOD-scid IL2rgamma(null) mice treated with alogliptin. Diabetes Metab Syndr Obes Target Ther. 2013;6:493-499.

51. Foley JE, Bunck MC, Moller-Goede DL, et al. Beta cell function following 1 year vildagliptin or placebo treatment and after 12 week washout in drug-naive patients with type 2 diabetes and mild hyperglycaemia: a randomised controlled trial. Diabetologia. 2011;54(8):1985-1991.

52. Eliasson B, Moller-Goede D, Eeg-Olofsson K, et al. Lowering of postprandial lipids in individuals with type 2 diabetes treated with alogliptin and/or pioglitazone: a randomised double-blind placebo-controlled study. Diabetologia. 2012;55(4):915-925.
53. Monami M, Lamanna C, Desideri CM, Mannucci E. DPP-4 inhibitors and lipids: systematic review and meta-analysis. Adv Ther. 2012;29(1): 14-25.

54. Shah Z, Kampfrath T, Deiuliis JA, et al. Long-term dipeptidyl-peptidase 4 inhibition reduces atherosclerosis and inflammation via effects on monocyte recruitment and chemotaxis. Circulation. 2011;124(21): 2338-2349.

55. Ta NN, Schuyler CA, Li Y, Lopes-Virella MF, Huang Y. DPP-4 (CD26) inhibitor alogliptin inhibits atherosclerosis in diabetic apolipoprotein E-deficient mice. J Cardiovasc Pharmacol. 2011;58(2): 157-166.

56. Yang D, Nakajo Y, Iihara K, Kataoka H, Yanamoto H. Alogliptin, a dipeptidylpeptidase-4 inhibitor, for patients with diabetes mellitus type 2 , induces tolerance to focal cerebral ischemia in non-diabetic, normal mice. Brain Res. 2013;1517:104-113.

57. Noda Y, Miyoshi T, Oe H, et al. Alogliptin ameliorates postprandial lipemia and postprandial endothelial dysfunction in non-diabetic subjects: a preliminary report. Cardiovasc Diabetol. 2013;12:8

58. Mega C, de Lemos ET, Vala H, et al. Diabetic nephropathy amelioration by a low-dose sitagliptin in an animal model of type 2 diabetes (Zucker diabetic fatty rat). Exp Diabetes Res. 2011;2011:162092.

59. Nakashima S, Matsui T, Takeuchi M, Yamagishi SI. Linagliptin blocks renal damage in type 1 diabetic rats by suppressing advanced glycation end products-receptor axis. Horm Metab Res. 2014;46(10): $717-721$.

60. Liu WJ, Xie SH, Liu YN, et al. Dipeptidyl peptidase IV inhibitor attenuates kidney injury in streptozotocin-induced diabetic rats. J Pharmacol Exp Ther. 2012;340(2):248-255.

61. Vavrinec P, Henning RH, Landheer SW, et al. Vildagliptin restores renal myogenic function and attenuates renal sclerosis independently of effects on blood glucose or proteinuria in Zucker diabetic fatty rat. Curr Vasc Pharmacol. 2014;12(6):836-844.

62. Fujita H, Taniai H, Murayama H, et al. DPP-4 inhibition with alogliptin on top of angiotensin II type 1 receptor blockade ameliorates albuminuria via up-regulation of SDF-1alpha in type 2 diabetic patients with incipient nephropathy. Endocr J. 2014;61(2):159-166.

63. Sakata K, Hayakawa M, Yano Y, et al. Efficacy of alogliptin, a dipeptidyl peptidase-4 inhibitor, on glucose parameters, the activity of the advanced glycation end product (AGE) - receptor for AGE (RAGE) axis and albuminuria in Japanese type 2 diabetes. Diabetes Metab Res Rev. 2013;29(8):624-630.

64. Scirica BM, Bhatt DL, Braunwald E, et al. Saxagliptin and cardiovascular outcomes in patients with type 2 diabetes mellitus. $N$ Engl J Med. 2013;369(14):1317-1326.

65. Avogaro A, Fadini GP. The effects of dipeptidyl peptidase-4 inhibition on microvascular diabetes complications. Diabetes Care. 2014;37(10): 2884-2894.

66. White WB, Pratley R, Fleck P, et al. Cardiovascular safety of the dipetidyl peptidase-4 inhibitor alogliptin in type 2 diabetes mellitus. Diabetes Obes Metab. 2013;15(7):668-673.

67. Monami M, Dicembrini I, Mannucci E. Dipeptidyl peptidase-4 inhibitors and heart failure: a meta-analysis of randomized clinical trials. Nutr Metab Cardiovasc Dis. 2014;24(7):689-697.

68. Clifton P. Do dipeptidyl peptidase IV (DPP-IV) inhibitors cause heart failure? Clin Ther. 2014;36(12):2072-2079.

69. Brown NJ, Byiers S, Carr D, Maldonado M, Warner BA. Dipeptidyl peptidase-IV inhibitor use associated with increased risk of ACE inhibitor-associated angioedema. Hypertension. 2009;54(3): 516-523.

70. Saisho Y, Itoh H. Dipeptidyl peptidase-4 inhibitors and angioedema: a class effect? Diabet Med. 2013;30(4):e149-e150.

71. Monami M, Dicembrini I, Martelli D, Mannucci E. Safety of dipeptidyl peptidase-4 inhibitors: a meta-analysis of randomized clinical trials. Curr Med Res Opin. 2011;27 Suppl 3:57-64.

72. Nauck MA. A critical analysis of the clinical use of incretin-based therapies: the benefits by far outweigh the potential risks. Diabetes Care. 2013;36(7):2126-2132. 
73. Elashoff M, Matveyenko AV, Gier B, Elashoff R, Butler PC. Pancreatitis, pancreatic, and thyroid cancer with glucagon-like peptide-1based therapies. Gastroenterology. 2011;141(1):150-156.

74. Singh S, Chang HY, Richards TM, Weiner JP, Clark JM, Segal JB. Glucagonlike peptide 1-based therapies and risk of hospitalization for acute pancreatitis in type 2 diabetes mellitus: a population-based matched case-control study. JAMA Intern Med. 2013;173(7):534-539.

75. Yabe D, Kuwata H, Kaneko M, et al. Use of the Japanese health insurance claims database to assess the risk of acute pancreatitis in patients with diabetes: comparison of DPP-4 inhibitors with other oral antidiabetic drugs. Diabetes Obes Metab. August 22, 2014. [Epub ahead of print.]

76. Giorda C, Sacerdote C, Nada E, Marafetti L, Baldi I, Gnavi R. Incretinbased therapies and acute pancreatitis risk: a systematic review and meta-analysis of observational studies. Endocrine. August 22, 2014. [Epub ahead of print.]

77. Scheen A. Alogliptin: concern about hepatotoxicity? Clin Pharmacokinet. 2014;53(11):1057-1059.

78. Butler AE, Janson J, Bonner-Weir S, Ritzel R, Rizza RA, Butler PC. Beta-cell deficit and increased beta-cell apoptosis in humans with type 2 diabetes. Diabetes. 2003;52(1):102-110.

79. Yoon KH, Ko SH, Cho JH, et al. Selective beta-cell loss and alpha-cell expansion in patients with type 2 diabetes mellitus in Korea. $J$ Clin Endocrinol Metab. 2003;88(5):2300-2308.

80. Sakuraba H, Mizukami H, Yagihashi N, Wada R, Hanyu C, Yagihashi S. Reduced beta-cell mass and expression of oxidative stress-related DNA damage in the islet of Japanese type II diabetic patients. Diabetologia. 2002;45(1):85-96.

81. Rahier J, Guiot Y, Goebbels RM, Sempoux C, Henquin JC. Pancreatic beta-cell mass in European subjects with type 2 diabetes. Diabetes Obes Metab. 2008;10 Suppl 4:32-42.

82. Skarfors ET, Selinus KI, Lithell HO. Risk factors for developing noninsulin dependent diabetes: a 10 year follow up of men in Uppsala. BMJ. 1991;303(6805):755-760.

83. Eriksson KF, Lindgarde F. Poor physical fitness, and impaired early insulin response but late hyperinsulinaemia, as predictors of NIDDM in middle-aged Swedish men. Diabetologia. 1996;39(5):573-579.

84. Weyer C, Bogardus C, Mott DM, Pratley RE. The natural history of insulin secretory dysfunction and insulin resistance in the pathogenesis of type 2 diabetes mellitus. J Clin Invest. 1999;104(6):787-794.

85. Haffner SM, Miettinen H, Gaskill SP, Stern MP. Decreased insulin secretion and increased insulin resistance are independently related to the 7-year risk of NIDDM in Mexican-Americans. Diabetes. 1995; 44(12):1386-1391.

86. Lyssenko V, Almgren P, Anevski D, et al. Predictors of and longitudinal changes in insulin sensitivity and secretion preceding onset of type 2 diabetes. Diabetes. 2005;54(1):166-174.

87. Tabak AG, Jokela M, Akbaraly TN, Brunner EJ, Kivimaki M, Witte DR. Trajectories of glycaemia, insulin sensitivity, and insulin secretion before diagnosis of type 2 diabetes: an analysis from the Whitehall II study. Lancet. 2009;373(9682):2215-2221.

88. UK Prospective Diabetes Study Group. UK Prospective Diabetes Study 16. Overview of 6 years' therapy of type II diabetes: a progressive disease. Diabetes. 1995;44(11):1249-1258.

89. Levy J, Atkinson AB, Bell PM, McCance DR, Hadden DR. Beta-cell deterioration determines the onset and rate of progression of secondary dietary failure in type 2 diabetes mellitus: the 10-year follow-up of the Belfast Diet Study. Diabet Med. 1998;15(4):290-296.

90. Saisho Y, Tanaka K, Abe T, Shimada A, Kawai T, Itoh H. Effect of obesity on declining beta cell function after diagnosis of type 2 diabetes: a possible link suggested by cross-sectional analysis. Endocr $J$. 2012;59(3):187-195.

91. Saisho Y, Kou K, Tanaka K, et al. Association between beta cell function and future glycemic control in patients with type 2 diabetes. Endocr $J$. 2013;60(4):517-523.
92. Saisho Y, Tanaka K, Abe T, Shimada A, Kawai T, Itoh H. Glycated albumin to glycated hemoglobin ratio reflects postprandial glucose excursion and relates to beta cell function in both type 1 and type 2 diabetes. Diabetol Int. 2011;2(3):146-153.

93. Saisho Y. Beta cell dysfunction: its critical role in prevention and management of type 2 diabetes. World J Diabetes. 2015;6(1): 109-124.

94. Muscelli E, Casolaro A, Gastaldelli A, et al. Mechanisms for the antihyperglycemic effect of sitagliptin in patients with type 2 diabetes. $J$ Clin Endocrinol Metab. 2012;97(8):2818-2826.

95. Solis-Herrera C, Triplitt C, Garduno-Garcia JD, Adams J, Defronzo RA, Cersosimo E. Mechanisms of glucose lowering of dipeptidyl peptidase-4 inhibitor sitagliptin when used alone or with metformin in type 2 diabetes: a double-tracer study. Diabetes Care. 2013;36(9): 2756-2762.

96. Muller WA, Faloona GR, Aguilar-Parada E, Unger RH. Abnormal alpha-cell function in diabetes. Response to carbohydrate and protein ingestion. N Engl J Med. 1970;283(3):109-115.

97. Del Prato S, Felton AM, Munro N, Nesto R, Zimmet P, Zinman B. Improving glucose management: ten steps to get more patients with type 2 diabetes to glycaemic goal. Int J Clin Pract. 2005;59(11): $1345-1355$.

98. DeFronzo RA, Abdul-Ghani MA. Preservation of beta-cell function: the key to diabetes prevention. J Clin Endocrinol Metab. 2011;96(8): 2354-2366.

99. Inzucchi SE, Bergenstal RM, Buse JB, et al. Management of hyperglycemia in type 2 diabetes, 2015: a patient-centered approach: Update to a position statement of the American Diabetes Association and the European Association for the Study of Diabetes. Diabetes Care. 2015;38(1):140-149.

100. Garber AJ, Abrahamson MJ, Barzilay JI, et al. AACE comprehensive diabetes management algorithm 2013. Endocr Pract. 2013;19(2): 327-336.

101. International Diabetes Federation Guideline Development Group. Global guideline for type 2 diabetes. Diabetes Res Clin Pract. 2014; 104(1):1-52.

102. Phung OJ, Scholle JM, Talwar M, Coleman CI. Effect of noninsulin antidiabetic drugs added to metformin therapy on glycemic control, weight gain, and hypoglycemia in type 2 diabetes. JAMA. 2010; 303(14):1410-1418.

103. Kahn SE, Haffner SM, Heise MA, et al. Glycemic durability of rosiglitazone, metformin, or glyburide monotherapy. $N$ Engl J Med. 2006;355(23):2427-2443.

104. Levin D, Bell S, Sund R, et al. Pioglitazone and bladder cancer risk: a multipopulation pooled, cumulative exposure analysis. Diabetologia. 2014;58(3):493-504.

105. Bangalore S, Kamalakkannan G, Parkar S, Messerli FH. Fixed-dose combinations improve medication compliance: a meta-analysis. $\mathrm{Am}$ J Med. 2007;120(8):713-719.

106. Hutchins V, Zhang B, Fleurence RL, Krishnarajah G, Graham J. A systematic review of adherence, treatment satisfaction and costs, in fixed-dose combination regimens in type 2 diabetes. Curr Med Res Opin. 2011;27(6):1157-1168.

107. Kurozumi A, Okada Y, Mori H, Arao T, Tanaka Y. Efficacy of $\alpha$-glucosidase inhibitors combined with dipeptidyl-peptidase- 4 inhibitor (alogliptin) for glucose fluctuation in patients with type 2 diabetes mellitus by continuous glucose monitoring. J Diabetes Invest. 2013;4(4):393-398.

108. Jabbour SA, Hardy E, Sugg J, Parikh S; Study 10 Group. Dapagliflozin is effective as add-on therapy to sitagliptin with or without metformin: a 24-week, multicenter, randomized, double-blind, placebo-controlled Study. Diabetes Care. 2014;37(3):740-750.

109. Weng J, Li Y, Xu W, et al. Effect of intensive insulin therapy on betacell function and glycaemic control in patients with newly diagnosed type 2 diabetes: a multicentre randomised parallel-group trial. Lancet. 2008;371(9626):1753-1760. 
110. Pennartz C, Schenker N, Menge BA, Schmidt WE, Nauck MA, Meier JJ. Chronic reduction of fasting glycemia with insulin glargine improves first- and second-phase insulin secretion in patients with type 2 diabetes. Diabetes Care. 2011;34(9):2048-2053.

111. Gerstein HC, Miller ME, Byington RP, et al. Effects of intensive glucose lowering in type 2 diabetes. $N$ Engl J Med. 2008;358(24): 2545-2559.

112. Lipska KJ, Ross JS, Wang Y, et al. National trends in US hospital admissions for hyperglycemia and hypoglycemia among Medicare beneficiaries, 1999 to 2011. JAMA Intern Med. 2014;174(7):1116-1124.

113. Vijan S, Sussman JB, Yudkin JS, Hayward RA. Effect of patients' risks and preferences on Health gains with plasma glucose level lowering in type 2 diabetes mellitus. JAMA Intern Med. 2014;174(8): 1227-1234.
114. Raz I, Riddle MC, Rosenstock J, et al. Personalized management of hyperglycemia in type 2 diabetes: reflections from a Diabetes Care Editors' Expert Forum. Diabetes Care. 2013;36(6):1779-1788.

115. Hsu WC, Boyko EJ, Fujimoto WY, et al. Pathophysiologic differences among Asians, native Hawaiians, and other Pacific Islanders and treatment implications. Diabetes Care. 2012;35(5):1189-1198.

116. Kodama K, Tojjar D, Yamada S, Toda K, Patel CJ, Butte AJ. Ethnic differences in the relationship between insulin sensitivity and insulin response: a systematic review and meta-analysis. Diabetes Care. 2013;36(6):1789-1796.

117. Kou K, Saisho Y, Satoh S, Yamada T, Itoh H. Change in beta cell mass in Japanese non-diabetic obese individuals. $J$ Clin Endocrinol Metab. 2013;98(9):3724-3730.
Vascular Health and Risk Management

\section{Publish your work in this journal}

Vascular Health and Risk Management is an international, peerreviewed journal of therapeutics and risk management, focusing on concise rapid reporting of clinical studies on the processes involved in the maintenance of vascular health; the monitoring, prevention and treatment of vascular disease and its sequelae; and the involvement of

\section{Dovepress}

metabolic disorders, particularly diabetes. This journal is indexed on PubMed Central and MedLine. The manuscript management system is completely online and includes a very quick and fair peer-review system, which is all easy to use. Visit http://www.dovepress.com/ testimonials.php to read real quotes from published authors.

Submit your manuscript here: http://www.dovepress.com/vascular-health-and-risk-management-journal 